\title{
Creatine and entrepreneurship
}

\author{
Cornelius A. Rietveld ${ }^{1}$ - Petri Böckerman ${ }^{2,3}$. \\ Jutta Viinikainen $^{4}$. Alex Bryson ${ }^{5}$. \\ Olli Raitakari6,7 • Jaakko Pehkonen ${ }^{4}$
}

(C) The Author(s) 2016. This article is published with open access at Springerlink.com

\begin{abstract}
Creatine is a nitrogenous organic acid which supplies energy to body cells and enhances physical performance. Using the Young Finns Study combined with the Finnish Linked employer-employee data we show that quantities of creatine measured in 1980 prior to labour market entry affect entrepreneurial success as measured by capital income accumulation over the period 1993-2010 (in particular for females). However, we do not find evidence that creatine affects the propensity to become an entrepreneur. Our study contributes to the emerging literature on biomarkers and entrepreneurship.
\end{abstract}

$凶$ Cornelius A. Rietveld

nrietveld@ese.eur.nl

Petri Böckerman

petri.bockerman@labour.fi

Jutta Viinikainen

jutta.viinikainen@jyu.fi

Alex Bryson

a.bryson@ucl.ac.uk

Olli Raitakari

olli.raitakari@utu.fi

Jaakko Pehkonen

jaakko.k.pehkonen@jyu.fi

1 Erasmus School of Economics and Erasmus University Rotterdam Institute for Behavior and Biology, Erasmus University Rotterdam, Rotterdam, The Netherlands

2 Turku School of Economics, University of Turku, Turku, Finland

3 Labour Institute for Economic Research and Institute for the Study of Labor, Bonn, Germany

4 Jyväskylä University School of Business and Economics, Jyväskylä, Finland

5 UCL Institute of Education, University College London, London, UK 
Keywords Creatine $\cdot$ Entrepreneurship $\cdot$ Self-employment

JEL Classification J24 · L26

\section{Introduction}

Occupational choice theory presumes that people become an entrepreneur if the total expected utility derived from entrepreneurship is higher than the utility they expect to derive from their best alternative employment option (Taylor 1999; Parker 2009). Utility entails more than income-entrepreneurs have, on average, a lower and more volatile income than people in paid employment (Hamilton 2000) - and includes utility derived from non-monetary factors such as independence and initiative (Taylor 1996). Individuals are thought to make an occupational decision in which the fit between an individual's characteristics and the job requirement is such that it results in the highest expected utility (Kristof-Brown et al. 2005).

There is a growing trend within entrepreneurship research to bring biological factors into these models of occupational choice. For example, some studies find that psychological traits such as narcissism (Mathieu and St-Jean 2013), Attention Deficit Hyperactivity Disorder (Verheul et al. 2015), and dyslexia (Hessels et al. 2014) are more prevalent amongst entrepreneurs. Other studies incorporate direct body-markers such as genes (Nicolaou et al. 2008; Van der Loos et al. 2013a, b), hormones (White et al. 2006; Van der Loos et al. 2013a, b; Greene et al. 2014) and height (Rietveld et al. 2015) in models of occupational choice. The current paper contributes to this emerging strand of empirical research by investigating the potential role of creatine in the decision to become an entrepreneur and its influence on being a successful entrepreneur. There are no earlier studies investigating this relationship.

Creatine is a nitrogenous organic acid which supplies energy to body cells. It enhances physical performance, for example in high-intensity exercise (Wyss and Kaddurah-Daouk 2000), and improves mental ability and cognition (Rae et al. 2003; Allen 2012). Therefore, greater effort intensity may result in labour market outcomes in which great effort is needed and rewarded as creatine reduces (increases) the costs (returns) to effort. For example, creatine has been linked to total income, earnings and employment years (Böckerman et al. 2014). Entrepreneurship is associated with high social status in many countries (Kelley et al. 2011) and typically requires greater physical effort than working as an employee (Buttner 1992; Stephan and Roesler 2010). Thus, high levels of creatine may be particularly valuable in pursuing an entrepreneurial occupation and also partly explain entrepreneurial success.

6 Research Centre of Applied and Preventive Cardiovascular Medicine, University of Turku, Turku, Finland

7 Department of Clinical Physiology and Nuclear Medicine, Turku University Hospital, Turku, Finland 
Creatine has also been linked to the Big Five personality traits (Ryman et al. 2011). The Big Five dimensions associated with increased levels of creatine in certain parts of brain overlap with those associated with entrepreneurship. Creatine is positively associated with Conscientiousness and negatively with Agreeableness, Extraversion, and Neuroticism. A recent literature review indicated that entrepreneurship and entrepreneurial performance is also positively associated with Conscientiousness and negatively with Neuroticism (Brandstätter 2011). Entrepreneurship is also negatively associated with Agreeableness. However, Extraversion is negatively associated with entrepreneurship and entrepreneurial performance. Other studies have found that higher Conscientiousness, lower Agreeableness and lower Neuroticism are associated with better labour market success in terms of earnings, job performance and employment (Heineck 2010; Almlund et al. 2011; Uysal and Pohlmeier 2011; Nandi and Nicoletti 2014). However, Extraversion seems to be positively associated with better labour market performance (Nandi and Nicoletti 2014). These studies lead us to expect a positive association between creatine and entrepreneurship.

\section{Materials and methods}

\subsection{Sample}

In 1980, 4320 children in six age cohorts (aged 3, 6, 9, 12, 15, and 18) were invited to participate in the Cardiovascular Young Finns Study (YFS). These children were randomly chosen from the population register in order to obtain a representative sample of Finnish children. The participants originated from five Finnish university regions and 3596 of the invited children participated eventually in the study (Raitakari et al. 2008). The aim of the study was to investigate how childhood lifestyle, biological, and psychological factors contribute to the risk of cardiovascular diseases in later life. Data have been collected through questionnaires, physical measurements and blood tests. The anthropometric measures are obtained during professional health examinations at local health centers.

\subsection{Entrepreneurship measures}

The YFS data are linked to Statistic Finland's Finnish Longitudinal employeremployee data (FLEED) to obtain information about involvement in entrepreneurship (self-employment status) and entrepreneurial success (capital income). The employment statistics record the exact labour market status during the last week of each year. Self-employment status is available for the period 1990-2010. A person is defined as an entrepreneur if the person has been self-employed at least once during the period 1990-2010. ${ }^{1}$ Self-employment is the most often used proxy for entrepreneurship in empirical research (Parker 2009). All other participants that have been at least one

\footnotetext{
1 In Sect. 3 we present robustness checks in which more strict measures for entrepreneurship are used.
} 
year in wage-work are defined as non-entrepreneurs (a small number of people who were never self-employed or employed were excluded from the analysis).

Entrepreneurial success is measured by the logarithm of average capital income. In 1993, Finland adopted a dual tax system (Kanniainen et al. 2007) where total income is divided into earned income and capital income (e.g. dividends, rental income, interest receipts, realized capital gains). Earned income is taxed under the progressive scale and capital income is taxed applying a flat rate. Entrepreneurial personal income from unlisted companies is divided into earned income and capital income by using a specific split rule that defines the maximum amount that can be allocated to capital income. The split rule is based on enterprise's net assets: higher net assets per share allow a higher share earmarked as capital income. Capital income is a useful metric for entrepreneurial success for two related reasons. First, the top marginal tax rates of earned income exceed the flat capital tax rate by a large margin. Thus, entrepreneurs with relatively high income have an economic incentive to transform entrepreneurial income into capital income to minimize the total amount of tax paid. As a result, capital income has a much larger variation than entrepreneurial income which makes it easier to identify the model. Second, capital income is a useful indicator of success, because the amount of capital income share is based on net wealth. As a result, successful entrepreneurs have more possibilities to withdraw capital income. To obtain a consistent time-series for capital income, we use capital income for the years 1993-2010, covering the period after Finland adopted a dual income taxation system. The long-term measure of capital income smoothes out yearly fluctuations, because capital gains are typically realized in a lumpy fashion. Capital income is measured in euros and deflated using the consumer price index (base year 2000).

\subsection{Creatine}

The YFS measured the amount of urine creatinine of the participants in 1980. Creatinine is the most important breakdown product of creatine and is considered to be a good proxy for creatine. The amount of creatinine was measured using standard urine drug tests, based on the Jaffe method (Delanghe and Speeckaert 2011). In the analyses creatinine is log-transformed. Some athletes use creatine as performance enhancing supplement (Wyss and Kaddurah-Daouk 2000), but this performance enhancing effect of creatine was not known in 1980 when creatine measurements in our sample were taken.

\subsection{Covariates}

For educational achievement we use an indicator for those who have obtained tertiary education (based on data from Statistics Finland on the highest obtained degree in 2010). Height and body fat were collected in 1980 and are standard biomarkers commonly used in empirical labour market research and therefore included in the regressions. To control for parental background we linked the YFS to the Longitudinal Population Census of Statistics Finland. As family background variables we use a binary variable indicating whether the mother and/or father was self-employed based 
on the information on their income from self-employment in 1980, and the parent's (log) total taxable annual income in 1980. In addition, gender, cohort and birth month indicators are included in the regressions.

\subsection{Statistical analyses}

We explain self-employment (over the years 1990-2010) and capital income (over the years 1993-2010) by the amount of creatine proxied by urine creatinine measured in 1980 using ordinary least squares (OLS) estimation. Because creatine has been measured before labour market entry, we can exclude the possibility that occupational status has influenced the levels of creatine in the body in 1980. Heteroskedasticity robust standard errors are used in all model specifications.

\section{Results}

The descriptive statistics for the participating individuals are reported in Table 1. Our sample consists of 3188 individuals of which $17 \%$ were registered as self-employed at least once during 1990-2010. Involvement in self-employment is higher among males (19\%) than among females (15\%). The average annual capital income in 1993-2010 is 814.97 euros in the total sample, and 1103.84 and 522.83 euros amongst males and females, respectively.

Table 1 Descriptive statistics for the analysis sample. Mean values of the variables are reported together with the standard deviations in parentheses

\begin{tabular}{llll}
\hline & Females + males & Females & Males \\
\hline Entrepreneurship measures & & & 0.19 \\
Ever self-employed (1990-2010) & 0.17 & 0.15 & $(0.39)$ \\
& $(0.37)$ & $(0.35)$ & 0.07 \\
Share of self-employment years (1990-2010) & 0.06 & 0.05 & $(0.20)$ \\
& $(0.18)$ & $(0.15)$ & 0.06 \\
At least 5 years of self-employment (1990-2010) & 0.05 & 0.04 & $(0.24)$ \\
& $(0.22)$ & $(0.19)$ & 3.35 \\
Logarithm of the average capital & 3.12 & $(2.89$ & $(3.00)$ \\
income 1993-2010 (Euros) & $(2.87)$ & & 1.99 \\
Biomarkers & & 2.03 & $(0.58)$ \\
Logarithm of creatinine & 2.01 & $(0.59)$ & 142.92 \\
Height (cm) & $(0.59)$ & 140.66 & $(27.03)$ \\
Body fat (kg) & 141.79 & $(23.90)$ & 11.71 \\
& $(25.54)$ & 21.88 & $(6.31)$ \\
\hline
\end{tabular}

$N=3188$. Biomarker information was obtained in 1980 when the participants were $3,6,9,12,15$ and 18 years old 
The regression results for self-employment are shown in Table 2. Creatine is neither significantly associated with self-employment in the main model specification (model 1), nor in the specification including controls for education and family background (model 2). Similar results are found for females (model 3 and 4) and males (model 5 and 6). We repeated the analyses reported in Table 2 using two other (more strict) measures for entrepreneurship. First, we used the share of years in self-employment. Second, we defined someone to be self-employment if (s)he had been at least five years in self-employment. In both cases, the regression coefficient for self-employment is close to zero and insignificant in all specifications.

The regression results for capital income are shown in Table 3. Creatine measured in childhood is positively associated with capital income in the regression amongst females and males (model 1). One standard deviation increase from the mean level of creatine is associated with a $10.7 \%$ increase in capital income. Because the average level of annual capital income in the period 1993-2010 was 814.97 euros, this converts to an increase of $\sim 87$ euros per year. ${ }^{2}$ The association remains significant after including controls for university education and parental income (model 2). These results alleviate the concern that factors such as inheritances (which are included in the measure for capital income) confound the estimated relationship between creatine and capital income. In the latter model an increase of $1 \%$ in the level of creatine increases capital income by $0.2 \%$, ceteris paribus. Models 3-6 show that the positive association between creatine and capital in the pooled females and males sample is largely driven by the subsample of females. The regression coefficient for creatine amongst females is positive and significant, but positive and insignificant amongst males.

We also performed the regressions for the subsample of the entrepreneurs. The regression results are shown in Table 4. In this model specification the regression coefficient for creatinine was 0.46 , which is higher compared to the one in total sample (0.24). Although the coefficient was statistically significant only at the $11 \%$ level, most likely because of substantially smaller sample size $(N=536)$, the result implies that the positive connection between creatine and capital income is pronounced among entrepreneurs and that creatine is related to entrepreneurial success. Again, the association between creatine and capital income is only significant for females and it remained significant after including parental income as control variable.

As a robustness check, we reran all regressions with control variables for meat and fish intake in 1980, because these may be confounding factors in the relation between creatine and entrepreneurship (Allen 2012). These analyses were based on somewhat smaller subsamples because of data availability, but the results (available upon request from the authors) are in line with the findings reported here.

\footnotetext{
2 The average level of creatinine in 1980 for all cohorts was 8.77 and the standard deviation within cohorts was 3.99. This implies that a one standard deviation increase from the average level of creatinine is equivalent to a $46 \%$ change. Since an increase in creatinine by one percent increases capital income by $\sim 0.23 \%$, a $46 \%$, or one standard deviation, increase in creatinine is associated with $\sim 10.7 \%$ increase in annual capital income.
} 


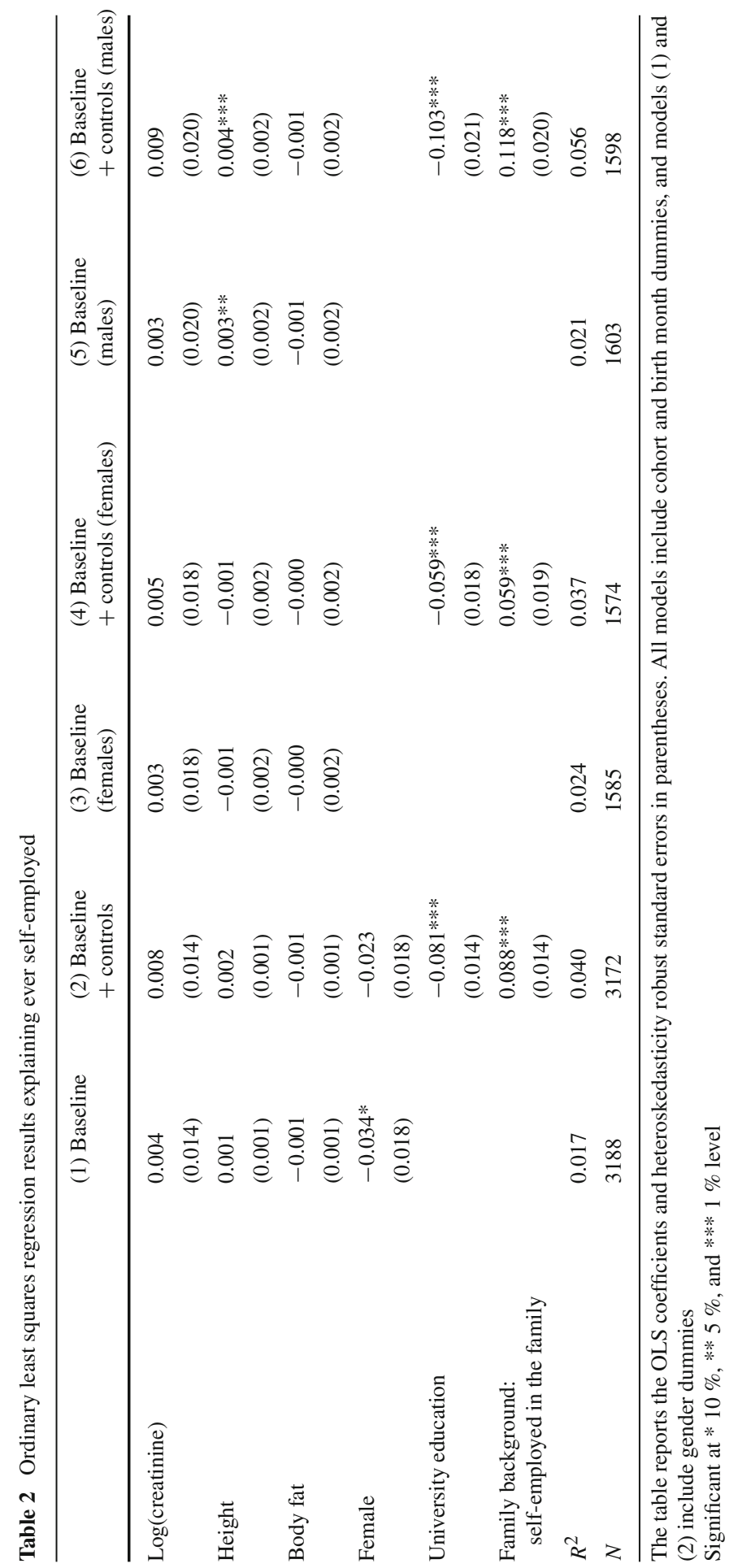




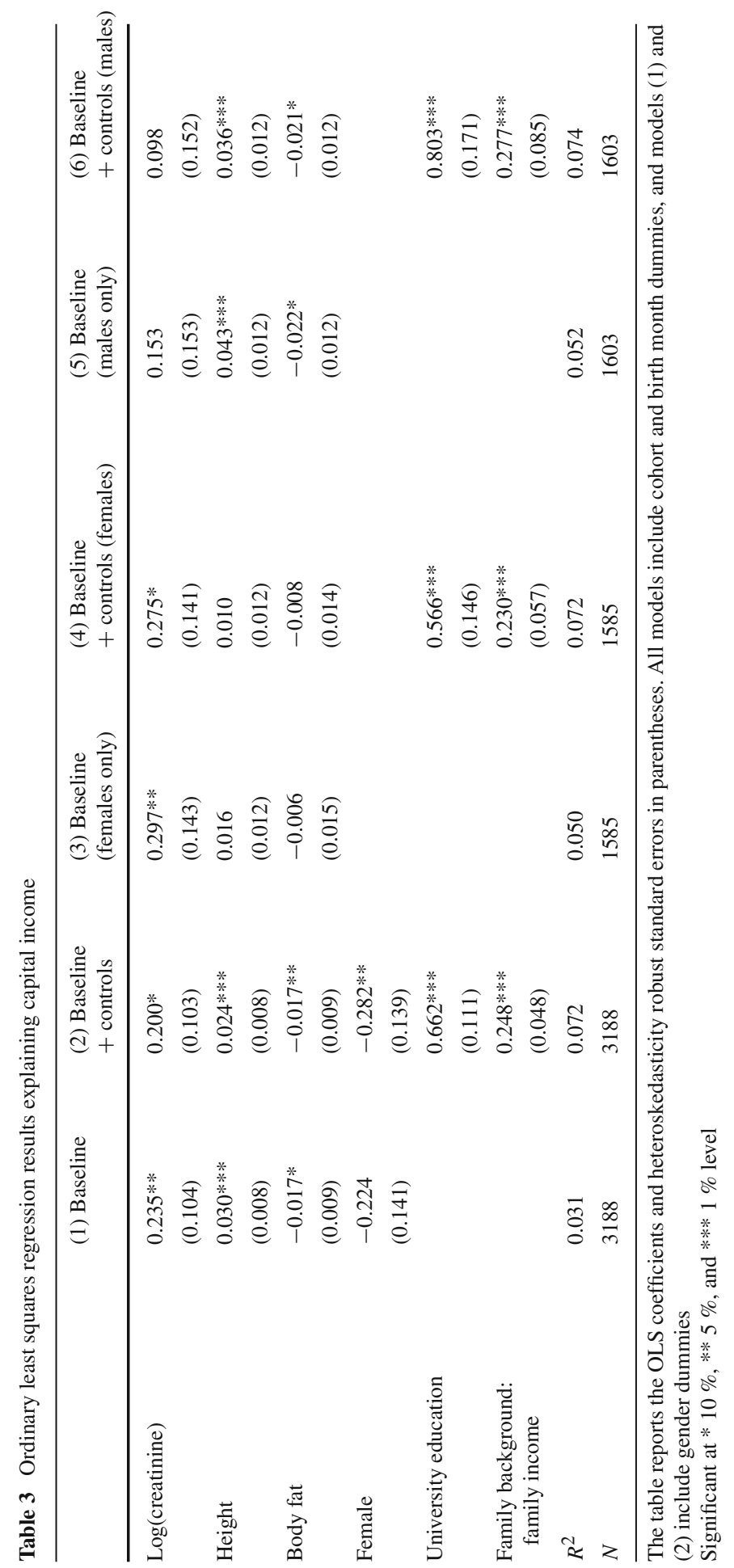




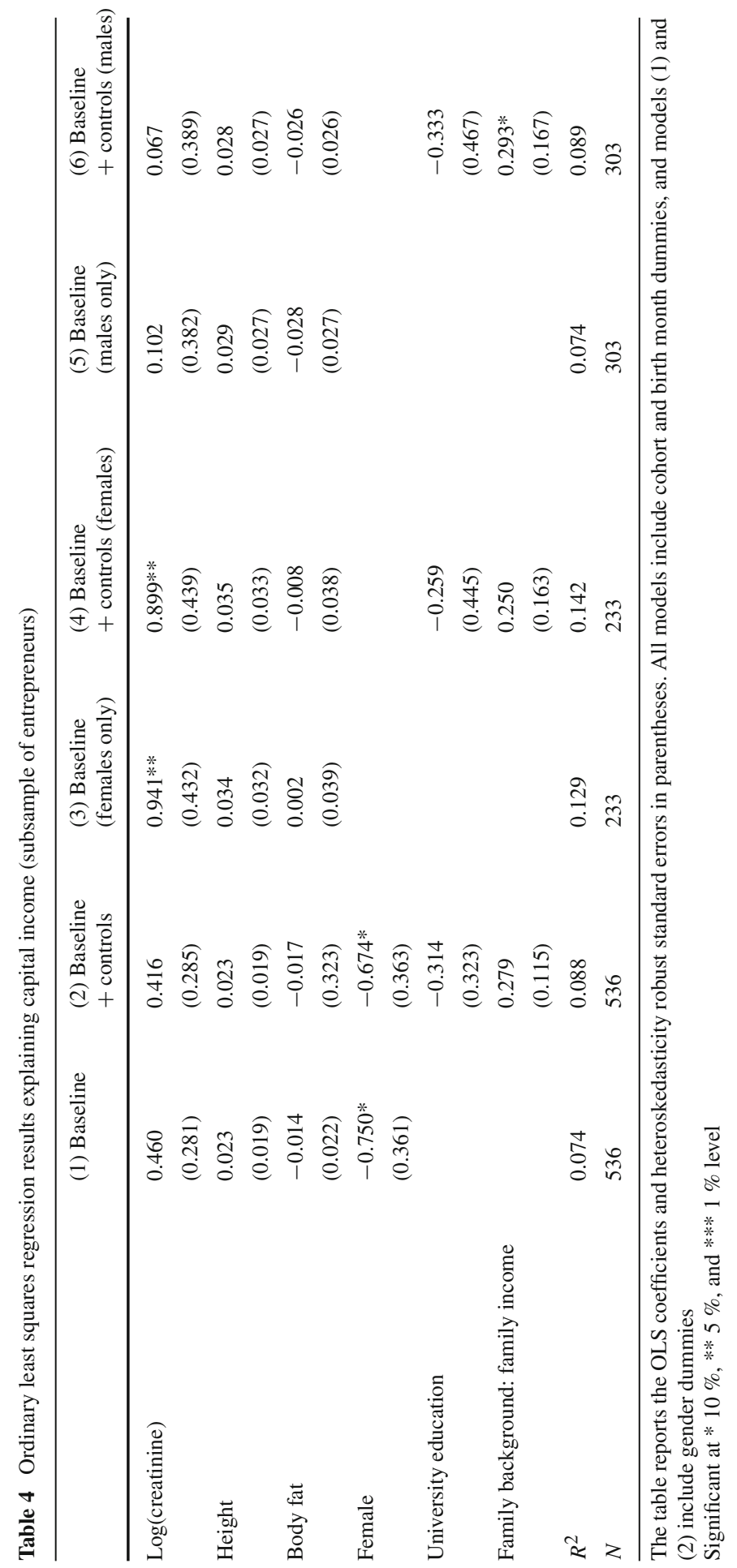




\section{Discussion and conclusion}

The empirical results using a longitudinal research design show that quantities of creatine measured in 1980 prior to labour market entry do not affect the propensity to become self-employed. However, they do affect entrepreneurial success as measured by capital income accumulation over the period 1993-2010. The latter result is only statistically significant for females, although the regression coefficient for males is also positive. The gender difference is not statistically significant $(p=0.49)$ and the insignificance of the regression coefficient for males could be due to the relatively small sample size in the gender stratified analyses. This finding could, however, suggest that success in entrepreneurship is more related to effort for females than for males.

Several reasons can account for the absence of a significant association between creatine and entrepreneurship. One of them is that our data do not allow us to distinguish between different start-up motivations of entrepreneurs. The entrepreneurship literature distinguishes entrepreneurs that start their business out of opportunity motives from those that start their business due to the lack of other employment opportunities (Reynolds et al. 2005). It is plausible that the inclusion of "necessity" entrepreneurs in our entrepreneurship measure weakens the link between creatine and being an entrepreneur. Register-based data do not permit us to make the distinction between these two types of entrepreneurship. However, our robustness check in which we used two different (more strict) measures for entrepreneurship confirmed our main findings.

In conclusion, using a large Finnish population-based sample, we do find evidence to support the hypothesis that creatine is associated with entrepreneurial success but it does not affect the propensity to become self-employed. Our findings for capital income are in line with (Böckerman et al. 2014) who show that creatine influences total income, earnings and employment years. Our findings for capital income-as our measure of entrepreneurial success-fit well with Böckerman et al's findings and the reasoning that creatine can affect performance and thus enhance labour market rewards. These findings contribute to our understanding of entrepreneurial success and enhance the emerging literature on the relation between biomarkers and entrepreneurship.

Acknowledgments The Young Finns Study has been financially supported by the Academy of Finland: Grants 134309 (Eye), 126925, 121584, 124282,129378 (Salve), 117787 (Gendi), and 41071 (Skidi), the Social Insurance Institution of Finland, Kuopio, Tampere and Turku University Hospital Medical Funds (Grant 9N035 and X51001), Juho Vainio Foundation, Paavo Nurmi Foundation, Finnish Foundation of Cardiovascular Research and Finnish Cultural Foundation, Tampere Tuberculosis Foundation and Emil Aaltonen Foundation. The use of linked data is supported by the Palkansaaja Foundation. Two of the authors acknowledge the financial support from the Yrjö Jahnsson foundation (Grants 6646 and 6664).

Open Access This article is distributed under the terms of the Creative Commons Attribution 4.0 International License (http://creativecommons.org/licenses/by/4.0/), which permits unrestricted use, distribution, and reproduction in any medium, provided you give appropriate credit to the original author(s) and the source, provide a link to the Creative Commons license, and indicate if changes were made. 


\section{References}

Allen, P. J. (2012). Creatine metabolism and psychiatric disorders: Does creatine supplementation have a therapeutic value? Neurosci Biobehav R, 36, 1442-1462.

Almlund, M., Duckworth, A. L., Heckman, J., \& Kautz, T. (2011). Personality psychology in economics. IZA Discussion Paper 5500.

Böckerman, P., Bryson, A., Viinikainen, J., Hakulinen, C., Pulkki-Råback, L., Raitakari, O., Pehkonen, J. (2014). Biomarkers and long-term labour market outcomes: The case of creatine. CEP Discussion Paper No 1279.

Brandstätter, H. (2011). Personality aspects of entrepreneurship: A look at five meta-analyses. Pers Individ Differ, 51, 222-230.

Buttner, E. H. (1992). Entrepreneurial stress: is it hazardous to your health? J Manag Issues, 4, $223-240$.

Delanghe, J. R., \& Speeckaert, M. M. (2011). Creatinine determination according to Jaffe-what does it stand for? Clin Kidney $J, 4,83-86$.

Greene, F. J., Han, L., Martin, S., Zhang, S., \& Wittert, G. (2014). Testosterone is associated with selfemployment among Australian men. Econ Hum Biol, 13, 76-84.

Hamilton, B. H. (2000). Does entrepreneurship pay? An empirical analysis of the returns to self-employment. J Polit Econ, 108, 604-631.

Hessels, J., Rietveld, C. A., \& Van der Zwan, P. W. (2014). Unraveling two myths about entrepreneurs. Econ Lett, 122, 435-438.

Heineck, G. (2010). Does it pay to be nice? Personality and earnings in the United Kingdom. Ind Labor Relat Rev, 64, 1020-1038.

Kanniainen, V., Kari, S., \& Ylä-Liedenpohja, J. (2007). Nordic dual income taxation of entrepreneurs. Int Tax Public Financ, 14, 407-426.

Kelley, D. J., Bosma, N., \& Amorós, J. E. (2011). Global entrepreneurship monitor: Global report 2010. St. Louis: Global Entrepreneurship Research Association.

Kristof-Brown, A. L., Zimmerman, R. D., \& Johnson, E. C. (2005). Consequences of individuals' fit at work: A meta-analysis of person-job, person-organization, person-group, and person-supervisor fit. Pers Psychol, 58, 281-342.

Mathieu, C., \& St-Jean, E. (2013). Entrepreneurial personality: The role of narcissism. Pers Individ Differ, $55,527-531$.

Nandi, A., \& Nicoletti, C. (2014). Explaining personality pay gaps in the UK. Appl Econ, 46, 3131-3150.

Nicolaou, N., Shane, S., Cherkas, L., Hunkin, J., \& Spector, T. D. (2008). Is the tendency to engage in entrepreneurship genetic? Manag Sci, 54, 167-179.

Parker, S. C. (2009). The economics of entrepreneurship. Cambridge: Cambridge University Press.

Rae, C., Digney, A. L., McEwan, S. R., \& Bates, T. C. (2003). Oral creatine monohydrate supplementation improves brain performance: A double-blind, placebo-controlled, cross-over trial. $P$ R Soc B, 270, 2147-2150.

Raitakari, O. T., Juonala, M., Rönnemaa, T., Keltikangas-Järvinen, L., Räsänen, L., Pietikäinen, M., HutriKähönen, N., Taittonen, L., Jokinen, E., Marniemi, J., Jula, A., Telama, R., Kähönen, M., Lehtimäki, T., Akerblom, H. K., \& Viikari, J. S. A. (2008). Cohort profile: the cardiovascular risk in Young Finns Study. Int J Epidemiol, 37, 1220-1226.

Reynolds, P., Bosma, N., Autio, E., Hunt, S., De Bono, N., et al. (2005). Global Entrepreneurship Monitor: Data collection design and implementation 1998-2003. Small Bus Econ, 24, 205-231.

Rietveld, C. A., Hessels, J., \& Van der Zwan, P. (2015). The stature of the self-employed and its premium. Econ Hum Biol, 17, 59-74.

Ryman, S. G., Gasparovic, C., Bedrick, E. J., Flores, R. A., Marshall, A. N., \& Jung, R. E. (2011). Brain biochemistry and personality: a magnetic resonance spectroscopy study. Plos One, 6, e26758.

Stephan, U., \& Roesler, U. (2010). Comparison of entrepreneurs' and employee's health in a national representative sample. J Occup Organ Psych, 83, 717-738.

Taylor, M. P. (1996). Earnings, independence or unemployment: Why become self-employed? Oxford Bull Econ Stat, 58, 253-266.

Taylor, M. P. (1999). Survival of the fittest? An analysis of self-employment duration in Britain. Econ J, $109,140-155$.

Uysal, S. D., \& Pohlmeier, W. (2011). Unemployment duration and personality. J Econ Psychol, 32, 980992. 
Van der Loos, M. J. H. M., Haring, R., Rietveld, C. A., Baumeister, S. E., Groenen, P. J. F., Hofman, A., De Jong, F. H., Koellinger, P. D., Kohlmann, T., Nauck, M. A., Rivadeneira, F., Uitterlinden, A. G., Van Rooij, F. J. A., Wallaschofski, H., \& Thurik, A. R. (2013a). Serum testosterone levels in males are not associated with entrepreneurial behavior in two independent observational studies. Physiol Behav, $119,110-114$.

Van der Loos, M. J. H. M., Rietveld, C. A., Eklund, N., Koellinger, P. D., Rivadeneira, F., Abecasis, G. R., Ankra-Badu, G. A., Baumeister, S. E., Benjamin, D. J., Biffar, R., Blankenberg, S., Boomsma, D. I., Cesarini, D., Cucca, F., De Geus, E. J. C., Dedoussis, G., Deloukas, P., Dimitriou, M., Eiriksdottir, G., Eriksson, J., Gieger, C., Gudnason, V., Höhne, B., Holle, R., Hottenga, J-J., Isaacs, A., Järvelin, M-R., Johannesson, M., Kaakinen, M., Kähönen, M., Kanoni, S., Laaksonen, M. A., Lahti, J., Launer, L. J.,Lehtimäki, T., Loitfelder, M., Magnusson, P. K. E., Naitza, S., Oostra, B. A., Perola, M., Petrovic, K., Quaye, L., Raitakari, O., Ripatti, S., Scheet, P., Schlessinger, D., Schmidt, C. O., Schmidt, H., Schmidt, R., Senft, A., Smith, A.V., Spector, T. D., Surakka, I., Svento, R., Terracciano, A., Tikkanen, E., Van Duijn, C. M., Viikari, J., Völzke, H., Wichmann, H. -E., Wild, P. S., Willems, S. M., Willemsen, G., Van Rooij, F. J. A., Groenen, P. J. F., Uitterlinden, A. G., Hofman, A., \& Thurik, A. R. (2013b). The molecular genetic architecture of self-employment. Plos One, 8, e60542.

Verheul, I., Block, J. H., Burmeister-Lamp, K., Tiemeier, H. W., \& Turturea, R. (2015). ADHD-like behavior and entrepreneurial intentions. Small Bus Econ, 45, 85.

White, R. E., Thornhill, S., \& Hampson, E. (2006). Entrepreneurs and evolutionary biology: The relationship between testosterone and new venture creation. Organ Behav Hum Decis Process, 100, 21-34.

Wyss, M., \& Kaddurah-Daouk, R. (2000). Creatine and creatinine metabolism. Psychol Rev, 80, 1107-1213. 